\title{
Persepolis po česku: Neslyšené hlasy íránských žen žijících u nás
}

\author{
Persepolis in the Czech Way: The \\ Unheard Voices of Iranian Women \\ among Us
}

\author{
Michaela Vaňková* \\ University of West Bohemia, Czech Republic
}

\begin{abstract}
The work deals with Iranian women in the Czech Republic, aiming to find out how the position and social status of these researched women in Czech society are to a large extent shaped and influenced by the culture of the country of their origin. The article follows the reasons why these women left Iran, as well as relatives and family pressure on women. Furthermore, it is the society and ubiquitous social control that has influenced a number of decisions in women's lives, including marriage to a foreigner and emigration. The text deals with the historical and cultural consequences that gave rise to patriarchy and the emergence of feminist movements and thoughts in the Islamic Republic of Iran, and also discusses the perception of gender issues and the general position of women in Iran from the perspective of Western authors. Based on semi-structured interviews, the text shows the lived experiences of the studied women who left their home country to escape the local controlling environment. These women literally get themselves into a different foreign culture carrying their own cultural burdens with them. For Czech society, Iranian women are practically invisible, but they struggle with the daily dilemma of keeping cultural attributes and ties of their homeland or liberating themselves completely. In addition to several topics related to the context of cultural transmission, the article discusses patriarchy and family, feminism and the public sphere, including the symbol of the veil, and education, which includes the defining potential for changing a woman's lifestyle. The text (as well as the final thesis) can help with thinking about the issue of integration.
\end{abstract}

\section{Keywords}

Iranian women, culture transmission, gender, feminism, patriarchy, Iranian culture, Czech Republic

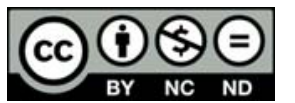

This paper is licensed under Creative Commons Attribution-NonCommercial-NoDerivatives 4.0 International License.

\footnotetext{
* Corresponding Author: Michaela Vaňková, Katedra antropologie, Fakulta filozofická Západočeské univerzity v Plzni, Sedláčkova 15, 30100 Plzeň. E-mail: vankovam@ksa.zcu.cz.
} 


\section{Úvod}

„Byla jsem považovaná za prostitutku. V té společnosti jú jsem. Mưžeš se ptát proč. A jak velký rozdil to je tady? [...] Tady jsem jako stín. Nikdo mě (doopravdy) nevidí"

(Informátorka A. 2020).

Text pojednává o problematice kulturní migrace, jejímiž nositelkami jsou íránské ženy žijící v České republice. Tyto ženy emigrovaly na Západ díky sňatku s Čechem motivované vymanit se z područí vlastní kultury, která se vyznačuje značnou mírou sociální kontroly, tlaku na jednotlivce a patriarchálním uspořádáním. Podařilo se těmto ženám íránské kultuře uniknout a změnit své postavení a status ve společnosti emigrací do Česka? Nakolik jsou tyto ženy ovlivňovány kulturním břemenem nesoucím si ze země původu a nakolik se jim daří začlenit se u nás? Na tyto otázky se snažím odpovědět v následujících odstavcích. Článek vychází z výzkumu, který je součástí dizertačního projektu Íránské ženy u nás. Jedná se o téma v českém prostoru takřka neviditelné, stejně tak jako jsou umenšované jeho hlavní hrdinky. Považuji za důležité věnovat se tomuto okrajovému tématu ve veřejné diskuzi proto, aby vyvstaly nové otázky týkající se procesu integrace cizinek. Nakolik je možná, chtěná a úspěšná, týká-li se íránských žen, potažmo žen z podobně komplikovaných, kulturně odlišných prostředí. V textu se zabývám poznatky vycházejícími z vlastního výzkumu v Česku, který stále pokračuje a navazuje na dílčí výzkum v Holandsku. Výzkumy porovnávám a doplňuji s dalšími podobnými projekty zahraničních autorů, kteří se ale věnovali převážně celým komunitám. ${ }^{1}$ Tento text předkládá výsledky výzkumu se specifickým vzorkem. Mnou zkoumané ženy mezi sebou sice udržují formální sociální kontakt, avšak netvoří společně homogenní celek. V otázce integrace a jejich sociálního postavení by tento aspekt měl teoreticky hrát svou roli, v následujících kapitolách ale vysvětluji, že kulturní determinace je v obou případech podobná otázce sebeurčení žen.

\section{O přǐčinách touhy po změně}

Článek pojednává o problematice kulturní migrace v kontextu genderu. Gender jako takový, ortnerovsky řečeno, je symbolickou či kulturní konstrukcí (Moore 1988: 12-13), a tak je možná trochu domýšlivé posuzovat a kategorizovat danosti cizí kultury optikou té vlastní. Tedy, v př́padě íránských žen, připisovat jim roli utlačovaných bytostí, jejichž životním úkolem je být matkami a zdržovat se převážně v soukromé sféře. Sexuální asymetrii ovšem sociální antropologové považují za univerzální a přítomnou ve všech kulturách. Ženskou podřízenost a genderovou nerovnost vnímám proto $\mathrm{v}$ tématu jaksi přirozeně a považuji za nutné čtenáře obeznámit s kořeny vlivu na změny potřeb íránských žen uplatnit se ve společnosti. Zkoumám, zda skrze transnacionální vazby a zažité kulturní vzorce tyto ženy s sebou nesou kulturní dědictví i v emigraci, v Česku.

Ona kultura byla utvářena také působením místních feministických hnutí zabývajících se genderem a do značné míry určujících, jaké role ženám připisovat. Jak proklamuje Henrieta Moore: „Je mnoho feminismü, stejně tak jako je mnoho antropologii " (Moore 1988: nestr.), nejinak je tomu v íránském prostoru. Feministické skupiny či myšlenkové směry, které úzce souvisí s utvářením kulturního klimatu v zemi a sebeurčením žen a jejich snaze o emancipaci existovaly a stále fungují v prostředí akademickém, v žurnalistické sféře, ale také na poli občanského aktivismu. Zjednodušeně je rozděluji do dvou kategorií, a to feminismus sekulární a feminismus islámský či muslimský.

\footnotetext{
${ }^{1}$ Komunitu v tomto textu chápu jako skupinu, která udržuje vzájemné kontakty a sdílí určité sociální či kulturní hodnoty. Více např́ílad Keller (2017).
} 
Počátky sekulární feministické větve se kladou na začátek 20. století v Egyptě a na konec stejného století připadá vznik islámské, teologické, linie feminismu. Oba směry si nemusely nutně konkurovat, spíše často vznikaly zároveň a reagovaly na podobná témata. Sekulární feminismus ve své době souvisel s požadavky na modernizaci a rovnost mužských a ženských práv v rámci koloniálního státu. Ženy napříč náboženskými denominacemi bojovaly za vlastní sebeurčení a právo volit, získávat vzdělání, pracovat, uplatňovat se ve veřejném prostoru. Dohromady s nábožensky založenými ženami všechny sdílely nespokojenost v oblasti rodinného práva v islámu, které bylo zásadní příčinou diskuze o změně státního a celospolečenského uspořádání. Zvláště polygamie a možnosti rozvodu představovaly ohnisko problémů. Tyto palčivé otázky se zdaleka netýkaly pouze Egypta a koloniálních státi̊, a ačkoliv se v některých z nich udály výrazné politické změny v právech žen na vzdělání nebo například volit, sekulární feminismus byl stále živý i po rozpadu kolonialismu (Hesová 2019: 29-30).

V 90. letech registruje západní odborná veřejnost feminismus islámský, který operuje se základním pilírem, a to Koránem a jeho výklady, interpretacemi a uváděním koránských nařízení v praxi (Hesová 2019: 29). Vzhledem k transformaci íránského společenského systému po Íránské islámské revoluci v roce 1979 bylo nasnadě, aby se feministický směr požadující změny v oblasti věrouky stal aktivním sociálním činitelem. V Íránu se kolem časopisu Zanán (Ženy) utvořil kruh ženských aktivistek. Tyto reformistky spolu s dalšími skupinami z celého Blízkého východu usilovaly o sebeurčení žen v rámci náboženství (islámu) a vznikaly tím rychleji, čím narůstal a sílil islamismus vyznačující se konzervatismem a snahou o udržení a upevnění patriarchálního modelu rovněž reprezentujícího íránskou teokracii (Hesová 2019: 30-31). Islámský feminismus lze také považovat za odpověd modernímu rodinnému právu, jehož principy vychází z genderové hierarchie a ženy staví do pozice marginalizované, diskriminované skupiny, která je zároveň ale sociálně a nábožensky činná. Islámská feministka a antropoložka Mír-Husajní tvrdí, že pro postrevoluční Írán platí paradoxní stav, v němž režim umistuje ženy do role občana druhé kategorie - ty samé ženy, které věřily v revoluci a spravedlnost islámu a stály pevně po boku mužů měnících historii. Právě tyto muže, kteři ve jménu islámu převzali veškerou moc, viní aktivistky z prohlubování sociální a právní nerovnosti (Hesová 2019: 32-33).

Patriarchální řád není produktem revolučních změn, íránská kultura fungovala na principu genderové hierarchie i před rokem 1979. V teologii se však mužská dominance nejvýrazněji projevila právě v porevolučních letech. Islámské feministky požadovaly nové interpretace kanonických textů, aby tak změnily tradici analýzy a exegeze posvátných textů muži. Ti zároveň s věděním přebírají také moc a transformují ji v právní praxi, která preferuje mužská práva nad těmi ženskými (Çevik 2013: 2). Očividně patriarchální systém určil ženě roli poslušné, případně potrestané bytosti. V teorii. Prameny nastiňují, že ve věci žádosti o rozvod, předložení manželské smlouvy či dědických sporů se praxe od stanovených pravidel lišila a žena vystupovala ve veřejném prostoru samostatně, domáhajících se svých práv poměrně úspěšně. Proto je potřeba naše vlastní premisy a uvažování o islámu podrobovat neustálým zpochybňováním, protože vykazují nepřesnosti až známky nevědomosti (Özel Volfová, Holt 2019: 18-19).

Odhlédneme-li od náboženství, patriarchát sám o sobě je pevně zakotven v struktuře a ideologii, které tvoří systém dominance. Ten vytváří, udržuje při moci a znovu produkuje autoritářství a sexistické hodnoty a praktiky různě se vyskytující tu v soukromé, tu ve veřejné sféře. Patriarchální struktury mohou působit přirozeně a nevyhnutelně či dokonce spravedlivě, a to etablováním politických, ekonomických a sociálních institucí a vztahů ve společnosti. Změní-li se některé z těchto materiálních podmínek, vzdor dominantnímu patriarchátu na sebe nenechá dlouho čekat burcujíc společnost směrem $\mathrm{k}$ ještě větším změnám dopadajícím na ženy i muže (Moghissi 1999: 207). 
Kromě dvou základních kategorií myšlenkových proudů v Íránu je zapotřebí doplnit ještě další specifické dělení, a to na feminismus městský a rurální. Podle socioložky Naqíbí se feministické snahy v Íránu snažily sejmout závoj utlačovaným ženám inspirujíce se domněle nadřazeným západním feminismem ve 20 . století, což výrazně přispělo $\mathrm{k}$ ještě zřetelnějšímu odcizení skupiny více tradičních žen či žen z venkovských oblastí a hlavního proudu íránského feministického diskurzu. Problematika tedy zahrnuje jak nerovný vztah západního a íránského (islámského) feminismus, tak i nestejnou životní a sociální úroveň žen privilegované třídy a žen pocházejících z nižší vrstvy obyvatelstva (Naghibi 2007: 44). Žen pocházející z venkovských oblastí, chudších či nábožensky založených rodin se také dotýká vyšší míra společenských omezení (Benjamin 2018: 101). Tyto ženy mají mnohem menší šanci na změnu svého sociálního statusu a také nejspíše nebudou mít možnost íránskou kulturu opustit, emigrovat do jiné země.

Z výpovědí mých informátorek vyplývá, že ony samy sebe považují za ty, ke kterým byl osud přivětivější. Ženy z venkovských oblastí se podle nich ocitají v zajetí kontroly rodiny a mužủ, kteří rozhodují o manželství, studiu i pracovních příležitostech. Podmínky života žen na venkově vidí jako bezvýchodné a neměnné s akcentem na fakt, že je tomu právě z důvodu nemožnosti vzdělat se na středních a vysokých školách. Jak vypráví informátorka N., je těžké uniknout okolním vlivům, ale také nátlaku rodiny, a místo, odkud pocházíte, určuje další ženin osud: „Víte, ty ženský z vesnic se můžou zdát jako takový chudinky. Přece jen o nich rozhoduji rodiče, otec nebo třeba strýc, ale matka $v$ tom taky hraje svou roli, ale oni si to třeba nemusi ani uvědomovat, že je něco špatně. Dneska ale díky internetu a televizi všichni vidí, jak je to venku, jinde. A tak už nechtěji to, co generace jejich rodiču - vdát se, mít děti a zůstat tak, doma" (Informátorka N. 2020a).

\section{Patriarchát v emigraci}

Bylo by naivní domnívat se, že všechny íránské ženy postrádají svobodnou vůli a možnost ji uplatnit, ale také, že všechny tyto ženy jedině s emigrací uniknou patriarchátu jako systémovému nástroji a jednomu ze společenských pilírů v Íránu. Ten naopak je kulturně zakořeněný a s obměnami přežívá přesun na Západ, do jiného kulturního prostoru, kde se často paradoxně ještě více utužuje. V holandském Haagu a Rotterdamu, kam jsem se vydala zpovídat íránské ženy, se ukázalo, že komunita etnicky, nábožensky či kulturně spř́izněných přistěhovalců je přísně střežena a chráněna muži. A opět jsou to muži, kteří rozhodují o životě žen. Během svého krátkodobého výzkumného pobytu jsem vynaložila nemalé úsilí, abych vůbec pronikla do tamní komunity složené převážně z Íránců, Iráčanů a Afghánců. Přesto jsem se za celou dobu nesetkala s jedinou ženou, která by byla ochotna participovat na výzkumu. Respektive jsem se seznámila s muži velmi ochotnými pustit mne do svého domu, do svého soukromí, a velmi vstřícnými zodpovědět všechny mé otázky směřující k ženám. Nenechali mne však přímo hovořit se svými ženami či dalšími členkami komunity. Tehdy, v roce 2018, jsem skrze vlastní kontakty navštívila i centra pomáhajícím uprchlíkům a azylantům přicházejícím ze zemí třetího světa, a tak bylo nasnadě vyložit si neúspěch ve vyhledávání informátorek ne jako neochotu, ale jako obavu z případných právních důsledků pro tyto osoby. Po čase jsem ale zjistila, že ženy samotné by byly ochotné setkat se, ale mužové komunity př́sně dohlíželi, zda, kdy a kde k setkání dojde, a nakonec jsem se i po smluvené schůzce shledala opět s mužskými zástupci komunity.

Důvodem pro utužení mužské dominance v emigraci mohou být například životní podmínky (nejen) pro ženy, ba dokonce zisk vyšší míry individuální svobody, možnosti uplatnit se ve veřejném prostoru a práva rozhodovat o svém uplatnění ve společnosti. Muži tak pěstují jakýsi nový typ patriarchátu (tedy ten nepodpořený politickým systémem, celospolečenským nastavením a normami) a mají narůstající tendenci ženy více kontrolovat. Kromě toho se ženy od počátku 
vyhýbají čemukoliv cizímu a neznámému, všemu novému, a tím více udržují atributy vlastní kultury (Moghissi 1999: 208). Otázkou kulturní migrace se zabývá také socioložka Moqísí, která studovala íránskou komunitou v Kanadě. Většina z jejích dotazovaných pocházela z městského nenáboženského prostředí střední třídy v Íránu, z velké části se jednalo o intelektuály, kteří odešli ze země z politických důvodů či vlivem represí ze strany religiózního režimu po převratu v roce 1979. Autorka vypozorovala, že hodnoty patriarchátu, genderová předurčenost a zjevná mužská nadřazenost v íránské komunitě ani s postupem času během života na Západě nezmizely (Moghissi 1999: 209).

Výzkumníci, kteří se pohybovali v prostředí celých komunit, dospěli k jistým všeobecným závěrům, které dokazují, že patriarchát zůstal jako otisk paměti předrevolučního i postrevolučního Íránu. Zdá se, že ženy bojují za rovné př́ležitosti nejen v zemi původu, ale nakonec i v emigraci. Já se setkávám se ženami vyskytujícími se u nás víceméně osamoceně. Při pátrání po precedentu, o nějž bych se mohla při výzkumu oprrít, opakovaně narážím na studie zabývající se podobným tématem, avšak většinou se jedná o vytvoření konceptů zahrnující celé rodiny nebo komunity. Společenské a politické priority i osobní touhy se skupinám íránských rodin, at již hovoříme o čistě nukleárních jednotkách anebo tzv. velkorodinách (dle pojmenování Edwarda Saida, „na území, kam nepatř̌ “, tedy v zemi, která není místem jejich původu) mění pro zachování důstojnosti a kulturní identity komunity. Rovnost žen a demokratická práva členů komunity jsou regulována či dokonce zanedbávána, aby tak komunita zůstala celistvá (Moghissi 1999: 207). Nesou si íránské ženy přicházející do české kultury skrze transnacionální vazby a virtuální kontakt s domovem podobné zažité vzorce?

\section{Metodologické poznámky}

Text se soustředí na dílči část výzkumu provedeného s prozatímním vzorkem zkoumaných íránských žen ${ }^{2}$ dlouhodobě ${ }^{3}$ žijících u nás. Terénní výzkum probíhal od dubna 2019 do dubna 2020 v několika městech ${ }^{4}$ České republiky, přičemž jeho součástí bylo vyhledávání a kontaktování dalších informátorek, a to metodou sněhové koule, využití sociálních sítí a výjimečně také zcela náhodně. Dílčí pasáž je věnovaná také menšímu výzkumu v holandském Haagu a Rotterdamu realizovaném v listopadu a květnu 2018, který se nakonec ukázal jako velmi přínosný pro doplnění tohoto textu ve smyslu tematizování jinou evropskou emigraci íránských žen. Ve výzkumu jsem využívala polostrukturovaných rozhovorů s dopředu vytyčenými oblastmi mého badatelského zájmu.

Základní výzkumnou otázku jsem podpořila podotázkami vztahujícími se k čtyřem vybraným okruhům témat, a to rodině, zahalování, veřejné sféře a (univerzitnímu) vzdělání. Tato témata jsou důležitými zdroji informací o vytváření schémat chování a jednání zkoumaných žen v životě v České republice. Úzce souvisí s celospolečenským uspořádáním v Íránu a organizací jeho společnosti. Rodina, stejně tak jako okolí určuje a ovlivňuje sociální status žen, včetně jejich odívání (či zahalování) a budoucí profesní směřování. Nastavení íránské společnosti a potažmo celé její komplikované kultury ovlivnila řada historických událostí souvisejících s ustanovením politické garnitury v zemi i neoddělitelnosti civilního a náboženského života. Je to právě feminismus, který udává další směr společenským změnám a podílí se minimálně na reflexi patriarchálního modelu íránské společnosti a s ním související sociální kontrolou.

\footnotetext{
${ }^{2}$ Informátorky v textu označuji počátečním písmenem jména (např. informátorka A.).

${ }^{3}$ Vzhledem k legislativním potížím získat trvalý pobyt či dlouhodobá víza pro Íránce v České republice jsem definovala jako dlouhodobý pobyt záměr informátorky dlouhodobě či trvale žít na území Česka. Dosavadní informátorky žijí u nás na základě manželství s českým občanem, případně zde studují a plánují zde žít.

${ }^{4}$ Kvůli stále probíhajícímu výzkumu města nespecifikuji.
} 
V samotném výzkumu prozatím figuruje nízký počet informátorek, a to sedm žen. Pro tento text jsem vybrala relevantní výpovědi pěti z nich. Vzorek zpovídaných žen není př́liš rozsáhlý vzhledem k tomu, že v České republice k 31. květnu 2020 žije na základě povoleného přechodného pobytu 343 a na základě povoleného trvalého pobytu 60 žen původem z Íránu (Ministerstvo vnitra České republiky 2020). Zvolená, pro tuto chvíli jediná možná metoda mne zavedla k ženám podobného sociálního prostředí, s podobným příběhem. Záměrně jsem však v této fázi výzkumu vyhledala a zpovídala ženy, které se skutečně do české kultury přivdaly, a ne ty, které zde na čas žijí s íránským partnerem. Tyto ženy totiž neplánují v Česku dlouhodobě žít, a tak by pro tuto studii nebyly jejich výpovědi stoprocentně validní. Na základě jiných výzkumů a pozorování či přenesených zkušeností a imaginací informátorek se dozvídám o životě žen odešlých z Íránu s íránským manželem či celou rodinou.

Zkoumané ženy pocházejí z dobře ekonomicky situovaných rodin (vyšší střední třídy). Tři z těchto žen pochází z města, z prostředí konzervativního, ne ortodoxního, ale ani ne liberálního, islámského vyznání. Všechny tyto ženy mají středoškolské a vysokoškolské vzdělání a disponují minimálně dvěma světovými jazyky, jako je angličtina a francouzština. Další žena pochází také z města, avšak z rodiny spíše nižší střední třídy, nemá dokončené středoškolské vzdělání a rodina je spíše tradičně uspořádaná a zoroastrovského vyznání. Výjimku tvoří poslední informátorka, která se neprovdala za Čecha, v Česku ale studuje s (neurčitým) cílem v zemi zůstat anebo případně odtud emigrovat do Kanady a usadit se tam. Tato žena pochází z velmi tradiční rodiny, i zde dodržuje přikázané zahalování. Všechny zpovídané ženy, vyjma zmiňované studující ženy, přišly do České republiky po sňatku nebo za účelem sňatku s českým mužem a jsou zde tedy z právního hlediska legálně.

$\mathrm{S}$ informátorkami jsem se scházela $\mathrm{v}$ neutrálním prostředí, případně př́mo $\mathrm{v}$ jejich domácnosti. Z rozhovorů jsem pořizovala audio nahrávky, jejich přepisy a opatřovala jsem si také terénní poznámky sloužící k doplnění informací, například o emocionální vypětí, případně dalších postřehů týkajících se chování zkoumaných žen anebo popisu jejich domácího prostředí (pokud se např́klad obklopují předměty odkazující na íránskou kulturu a jsou s ní tedy v dennodenním kontaktu).

Velikost vzorku prozatím nepovažuji za nevýhodu, naopak informace, které jsem doposud získala, mi poskytují mnoho námětů pro další bádání, avšak uvědomuji si, že značná roztříštěnost idejí, ale také praktická stránka věci, jako je nutnost cestovat do rozličných koutů Česka a komplikovaný př́ístup k vyhledání a navázání nových kontaktů, bude v nejbližší době výzkum brzdit. Naopak vstřícnost a ochota oslovených žen spolupracovat slibuje optimistický výhled.

\section{Výzkumná subtémata}

Co se rodiny týče, informátorek jsem se ptala na rodinné zázemí - tedy jaké složení má, nebo měla domácnost, ve které vyrůstaly, zda se na jejich výchově podíleli oba rodiče, či spíše matka nebo spíše otec, zda se do výchovy zapojovala i širší rodina včetně prarodičů, strýců a tet. Zajímal mne také vztah k oběma rodičům a především k matce, jelikož jsem předpokládala, a bylo mi to potvrzeno, že určité aspekty výchovy (jak se správně chovat v rodině i na veřejnosti, jak se oblékat, jak se stát dobrou manželkou a matkou, jak komunikovat a jak ne) má na starosti matka, respektive vztah matky a dcery je pro momentální i další život dcery naprosto zásadní. Zároveň navenek má v íránsko-islámské kultuře otec roli hlavy rodiny, a má to být právě on, kdo zajistí, aby se jeho děti chovaly podle společenského úzu a linie rodiny zůstala zachována. Proto ani manželství není věcí samotné ženy, ale celé její rodiny (Nassehi-Behnam 1985: 557). Na základě porovnávání íránské a české kultury a našich (nakonec sdílených) zkušeností týkajících se generačních rozdílů a nedorozumění jsem nastolila další téma rozhovoru, a to otázku vměšování se 
sousedů a cizích lidí do soukromých záležitostí. Tedy nakolik postoje a rozhodnutí rodiny ovlivňují sousedé či známí. Zda rodina přizpůsobuje životní styl a upravují vnější obrázek o sobě v důsledku tohoto typu sociální kontroly.

Jedním z témat, které jsem původně pro jeho četnost ve veřejné diskuzi nezamýšlela rozebírat, byl způsob oblékání - konkrétně přístup rodiny a partnerů či okolí k zahalování ženy. Otázka povinného zahalování v Íránu a jeho vynucování rodinou či společností ale zaznívala v každém rozhovoru s informátorkami, a tak jsem došla k závěru, že šátek není symbolem svobodné vủle a přeneseně také patriarchátu z pohledu Západu a etnocentrických představ, ale i z pohledu zpovídaných žen, a zařadila jsem téma do textu jako zvláštní entitu. Propojuji ho se sociálním nátlakem, který se promítá do různých sfér života, nejviditelněji se ale projevuje právě ve fyzickém vzhledu žen.

Kromě toho mne zajímalo, zda je autoritou v životě žen také ostatní společnost. Zda a jak se musely přizpůsobovat svému okolí a zda se cítily ve veřejné oblasti omezovány. Vycházela jsem z historických informací, které poukazují na omezenou možnost svobodného pohybu žen na veřejnosti, kterou můžeme pojmout z různých úhlo̊ pohledu, at už se podíváme směrem nutnosti povolení muže, aby žena mohla pracovat, anebo výše zmiňovaný symbol zahalování. Skrze rozhovory ovšem zaznívaly především premisy, které odkazovaly opět k patriarchátu a také feminismu.

Jako poslední téma zařazuji do stati studium na univerzitě, případně možnosti uplatnit se na trhu práce. Otázky směřovaly k výběru studovaného oboru, zasahování rodiny do rozhodovacího procesu, úspěšnosti ukončení studia, následných pracovních zkušeností a pozadí, které ovlivňovalo individuální zkušenosti zkoumaných žen.

\section{Analýza}

V následující kapitole podrobím výzkumné podotázky analýze, kterou zakládám také na vybraných sociologických či antropologických zjištěních. Výpovědi informátorek problematizuji či zasazuji do myšlenkových rámců, přičemž ponechávám a přiznávám i citace, které obsahují zažité kategorizování či generalizace. Např́́klad se jedná o termíny promoderní a antimoderní Íránce jako prototypy binárních opozic, na které upozorňuje už socioložka Mitra Rastegar. Zjednodušující pojmenování a zevšeobecňování ukazuje na konkrétním příkladu, a to když podrobuje kritice knižní bestseller íránské autorky Ázar Nafísí Reading Lolita in Tehran: A Memoir in Books (v českém překladu jako Jak jsme $v$ Teheránu četly Lolitu). Rastegar se zde zabývá představením íránských žen prostřednictvím díla Nafísí jako obětí násilí ze strany státu (Íránu) a prezentováním protipólů barbarského íránského režimu a demokratického étosu obsaženého v západním románu. Jako zástupci opozičních sil vưči ženám vystupují muži, konkrétně ti angažovaní v náboženských institucích. Rastegar líčí osobní memoáry spisovatelky Nafísí jako poupravenou, personalizovanou historii, která jako literární produkt má za cíl lidi (za)bavit a předesílá, že je problematické považovat vzpomínky, ač založené na vlastní zkušenosti, jako historická fakta a platnou skutečnost (Rastegar 2006: 108-109).

Ve výzkumu výpovědi informátorek považuji za relevantní do té míry, do jaké odrážejí vlastní prožitky a zkušenost zpovídaných. Domnívám se, že vlastní vzpomínky nelze výzkumníkovi předat bez zatížení okolními vlivy, jako je společenská norma, historické konotace, sociální prostředí. Informátorky se často a velmi pravděpodobně nevědomky dopouštěly takzvané sociální žádoucnosti - ve snaze zavděčit se mně jako kandidátce antropologie odpovídaly tak, jak si myslely, že se od nich očekává (Janeček 2014: 81). Kromě podání svědectví založených na osobních prožitcích a vjemech mnohdy přidávají ještě zobecňující závěry a vlastní stanoviska posuzující situaci ostatních žen. Jako by s vyprávěním vlastního příběhu zároveň vlastní výpovědi interpretovaly a do jisté míry je samy podrobovaly analýze. Odpovědi jsou tedy často subjektivními shrnutími disku- 
tovaného problému zahrnujícího nejen zkušenosti informátorek, ale také přenesené zážitky či vyprávění a odpovědi, které považují za žádané. Vždy přitom zdưrazňují, že vychází z vlastního známého sociálního prostředí, ve snaze obejmout větší množství zajímavých informací se ale nevyhnou jistým generalizacím, stejně tak jako my, kteří zkoumáme ty druhé. Považuji za přirozené, že autobiografie, at již ve formě beletristického díla anebo nahrávky či přepisu rozhovorů, bude vždy prostoupena subjektivním vnímáním světa informátorů i výzkumníka. Jako ukázku uvádím jednu z citací informátorky M., která hovoří o vztazích s íránskými muži, které sama nikdy neprožila:

„Mít iránský vztah je hodně složitý, proto se hodně párů z Íránu, třeba moji bratranci, kteři se vzali v Íránu a potom odešli, v cizině rozvedli. On chtěl jít někam s holkama, ona s chlapama. Protože chtěli zažít věci, který v Íránu nemohli. A nakonec byli na nervy, protože každý chtěl toho druhýho chránit nějak [...] Když chtěl jít bratranec třeba na vánoční večírek s kamarády, ona dělala doma dusno [...]" (Informátorka M. 2019b).

Ženy tohoto výzkumu jsou víceméně individuálními členkami jakési imaginární imigrantské komunity, která je tvořena z lidí sice stejného, íránského, původu, avšak jiných životních cest, rodinného pozadí, osudů a důvodů přesunu (natrvalo) daleko od domova. Rodina ve fázi přesídlení a osamocení vlastní kultury zasazené do kultury cizí, západní, hraje nezastupitelnou roli, mnohdy zastiňuje či nahrazuje potřebu setkávat se s okolní, domácí, společností. Jedním z důvodů odchodu z mateřské země pro zpovídané ženy je právě rodinný tlak a snaha rodičů i širší rodiny mít život dcery pod kontrolou. Tento tlak neexistuje sám o sobě, nevytváří se izolován v jednotlivých rodinách, ale je přítomen již v samotné kultuře, která na její jednotlivé členy i celé sociální jednotky klade morální nároky a jejich dodržování nechává, kromě práva, na společnosti samé prostřednictvím sociální kontroly, např́iklad jakýchsi sousedských hlídek. Z hlediska íránské kultury, která úzce souvisí s kulturou islámskou, bychom ale termíny tlak či kontrola mohli nahradit (ačkoliv to jistě neplatí beze zbytku) slovem ochrana. Žena podle konceptu cti není nikdy ponechána nechráněna a o její ochranu se stará právě rodina, která funguje na principu patriarchátu a patrilinearity. Ochrana je zajištována skrze rozhodovací práva v procesu seznamování s potenciálním partnerem, manželství a rodičovství a také skrze zahalování (Nassehi-Behnam 1985: 558).

„Když vidíte ten film Persepolis, tak ta holka, co to napsala, je asi o pět let starši než já. A přesně v takové situaci jsem i já chodila do školy, během války v 90. letech. ${ }^{[5]}$ Tedy v rodině, kde se moje máma vždycky modlila a mưj táta četl marxismus, takže k nám chodili vždycky divný lidi a všichni se hádali, co je a není správné. [...] Takže já jsem [si] musela v hlavně všechno srovnávat. Když jsem byla v pubertě, krůček po krůčku jsem získávala svoji svobodu, protože máma myslela na to, že jsme (se sestrami) holky a nemáme bratry a můj táta je $k$ ničemu, takže [ona] nás musí nějakým způsobem chránit" (Informátorka M. 2019).

Informátorka M. hovořila především o nátlaku matky, která v rodině zastupovala roli vychovatele, kontrolora a strážce dobrých mravi̊. Zároveň ale uvedla i silný vliv rodiny z matčiny strany, která patřila $\mathrm{k}$ silně věřícím a tradici udržujícím lidem. Zvyklostí tedy bylo separovat chlapce a dívky od školního věku, když si hráli venku, od věku puberty dívek je také zaopatřit šátkem a zakrývat jim vlasy, podle tradice se pravidelně každý den modlit a kontrolovat, zda dívky svým jednáním nenarušují přísná pravidla morálky. Žena navzdory vlastnímu nezájmu k náboženství a tradici dodržovala pokyny své matky, tety a babičky.

Během středoškolského studia vlivem globalizujícího se světa a satelitnímu vysílání, ale také díky pozorování rodinných zvyklostí svých spolužáků začínala zjištovat, že svět jejích rodičů není jejím světem. Nebojovala už pouze s matkou, ale také s otcem, který představoval roli ochránce rodiny navenek. Ač se s matkou neshodoval ve věcech náboženství, záleželo mu na přijetí okolím

\footnotetext{
${ }^{5}$ Informátorka má na mysli válku s Irákem, která započala roku 1980 a fakticky trvala 8 let, avšak její sociální a ekonomické důsledky přetrvávaly ještě dlouho v 90 . letech, a která také znamenala období sjednocení a narůstajícího tlaku konzervatismu a potlačování ženské sexuality (viz např́klad Axworthy 2014: 203-205).
} 
a společností. Věta Co by tomu řekli lidi je z velké části symbolem odchodu informátorky M. ze země. Narůstající modernizace a globální svět versus upjatá íránská společnost, již okleštují nejméně dvě generace stará pravidla morálky a kulturní zásady, uspíšila svatbu s cizincem a emigraci. Rodinný tlak byl důvodem a motivací k útěku také pro další ze zpovídaných žen:

„Můj vztah s rodiči byl takový normální, po íránsku. To znamená, že jsme se navzájem tolerovali do té míry, dokud mně to vyhovovalo v rámci vlastní osobní svobody a oni necítili káravé pohledy okolí. Když jsem si postavila hlavu a nechtěla se podř́dit předem naplánovaným krokưm jít na technický obor a vdát se, musela jsem odejit" (Informátorka S. 2020).

Rodina upravuje také odívání žen a je to slovo závoj, které také vyniká napříč spektrem zmiňovaných feminismů. Jako jedno z vysvětlení nabízí Naqíbí: muži a ženy ze Západu považují závoj za symbol bariéry - ve smyslu přiblížit se Orientu -, zatímco pro muže z Orientu je závoj symbolem národní a kulturní cti. Navzdory tomu, že zahalené či nezahalené tělo je vesrkze ženské, zahalování, či nezahalování jej činí otázkou cti a váženosti muže v jeho sociálním prostředí. V Íránu se závoj či zahalení dokonce stal symbolem imperialistického odporu vedoucího až k revolučnímu roku 1979 (Naghibi 2007: 50-54). Ve výpovědích mých informátorek se v kontextu odchodu ze země a důvodů, proč nedokázaly v Íránu svobodně žít, otázka zahalování objevuje rovněž. Závoj prezentovaný šátkem zakrývajícím vlasy či čádorem zakrývajícím celé tělo, je v jejich vyprávění nástrojem moci nejen mužů, ale také matek, rodičovské síly, sousedské kontroly, zkrátka zahalení ovládá jejich přístup ke svobodě, volnému pohybu a samostatným rozhodnutím. Šátek dokonce v jedné informátorce vzbuzuje odpor, který ji jako mladé dívce zabraňoval nechat vyniknout kráse (Informátorka M. 2019b). Jak jsem psala již výše, otázka zahalování a konkrétně šátek pro mé informátorky stanul jako symbol svobody nejen svojí, ale také svého okolí a ostatních žen.

At již se náš rozhovor stočil směrem k náboženství, běžnému rodinnému životu, dětství anebo procesu emigrace, šátek byl obsažen v každé z odpovědí. Odložení šátku je také nejviditelnější změna, kterou život v emigraci mnohým ženám přinesl. Zdá se ale, že vizuální osvobození se neznamená skutečný posun: „Tady sice nenosím šátek, a nejradši bych ho nenosila ani doma, ale můj vzhled mě stejně odsuzuje být ve společnosti stranou. V̌̌ichni vidí, že nejsem odtud, že jsem jiná" (Informátorka N. 2020b). V emigraci tedy znovu ženy řeší způsob odívání, vlastní vzhled a mnohdy jej považují za překážku v socializaci.

Co se týče veřejné sféry, z výzkumu vychází, že pouze jedna z žen dokáže zaujmout aktivní pozici ve společnosti, a to především díky jazyku. Informátorka M. jako jediná z doposud zkoumaných žen ovládá češtinu na velmi dobré úrovni a také pracuje. Ostatní ženy se česky učí, s menšími pauzami a obtížemi, a nepracují, vyskytují se převážně doma. Finančně a do značné míry i v praktickém životě jsou odkázány na českého manžela. Pro informátorku Z. (jako jediná z žen pochází z nižší střední vrstvy, z rodinného prostředí tradičního, ale ne islámského, nýbrž zoroastrovského, a ukončila základní vzdělání ${ }^{6}$ ) se v Česku v ohledu participace ve veřejné sféře nic nezměnilo. V Íránu se s nedokončenou střední školou věnovala výrobě tradičních tkanin se svou matkou a další tkadlenou a většinu svého času nacházela doma. Nestýkala se ani s žádnými dalšími ženami. Dle vlastních slov jí být doma vyhovuje. „Mám ráda být doma. Nestýkám se s nikým, ale moc ráda doma privítám rodinu nebo prátele manžela. Neumím moc jazyk, tak se neobejdu bez překladů, to zvládá manžel" (Informátorka Z. 2019). Patriarchální uspořádání rodiny v Íránu tato žena v mírné obměně prožívá i v Česku. Jen zde roli ochránce, kterou doma představovali otec a bratr, vyměnila za úplnou závislost na manželovi.

\footnotetext{
${ }^{6}$ Informátorka Z. oficiálně ukončila systém základního školství, avšak absolvovala také dva roky úrovně středoškolské, kterou nedokončila. Doplňuji, že íránský vzdělávací systém je odlišný od českého: základní vzdělání se dělí do několika úrovní na stupeň od věku dětí 6-10 let a stupeň od věku dětí 11-13 let), středoškolské vzdělání navštěvují děti mezi 14-17 lety. Všechny úrovně vzdělání se také dělí na různé směry zaměření, at už je to např́klad technický, sociální, politický či ekonomický směr. Vzdělání je možné na státních i privátních školách a výuka funguje odděleně pro dívky a chlapce (viz např́klad Mehran 2003: 324).
} 
Na předchozím příkladu je vidět patrný rozdíl mezi ženou pocházející z tradičního rodinného uspořádání, bez vzdělání, a ženami, které kladou důraz na vlastní vzdělání a nezávislost. Ty nemohou, dle vlastních slov, nalézt Íránce s otevřenou myslí, takového, který si ženy svobodné mysli a odpovídajícího chování váží (Benjamin 2018: 103). Informátorky M. a N. potvrzují, že jedním z důvodů, proč nežijí v Íránu a proč ze země odešly, byla právě nemožnost vybudovat vztah s íránským mužem, který by je nekontroloval a nebyl dominantní. Nedokázaly si představit vztah s mužem z Íránu ani za podmínek, že by s ním žily mimo zemi, at již v České republice, jinde v Evropě, či na Západě obecně. Myslí, že íránští muži aspirují jednoznačně na vztahy, ve kterých rozhodují a řídí život svůj, partnerčin i jejich dětí právě oni. Nepochybuje o tom, že by ženě dovolili vzdělávat se či pracovat, tedy nevylučuje ani zapojení se ženy ve veřejné sféře, avšak zdůrazňuje, že pro veškeré takové aktivity by stejně žena potřebovala povolení svého manžela a tím by přišla o stoprocentní míru svobodné vůle (Informátorka M. 2019a, Informátorka N. 2020a).

Dalším aspektem, který může vést $\mathrm{k}$ uvědomění si přání žen rozhodovat o svém životě, je možnost univerzitního vzdělání. Ve skutečnosti hraje důležitou roli v íránské společnosti. Teheránská univerzita přijímala studentky od svého otevření v roce 1935 a vysokoškolské vzdělání se v té době stalo jakousi normou pro Íránce střední až vyšší společenské třídy. Informátorka S. vzpomíná, že již pro generaci její matky bylo více než žádoucí, aby jako žena z lepší rodiny dosáhla patřičného vzdělání.

„Už pro mou matku bylo úplně samozřejmé jít na vysokou. Přirozeně jí byl ale obor vybrán rodiči a později se ani nepokusila se pracovně uplatnit. Ale jako žena z lepši rodiny jít měla a musela. A tak to bylo i pro mě a mou sestru. Jen my už jsme si chtěly vybrat obor samy, a to jsme nesměly" (Informátorka S. 2020).

Rodina určila, který z nabízených oborů se jeví perspektivněji, a často jej vybrala sama. Informátorka N. také spolu se sestrou toužila po studiu umění, avšak technický obor slibující inženýrskou dráhu se rodině zdál př́íhodnější. Informátorka M. dodává, že studium sloužilo některým jejím spolužačkám spíše k ukrácení dlouhé chvíle a kromě docházení na přednášky se nezapojovaly do dalších aktivit. Protože univerzitní stupeň vzdělání již mohou navštěvovat obě pohlaví, konzervativnější ženy byly do školy přiváženy a opět odváženy otci a po absolutoriu byly provdány. Po svatbě tyto ženy nikdy nepracovaly.

Co se pracovní sféry týče, v minulosti ženy nebyly viděny na vybraných pracovních pozicích ze sociokulturních důvodů a kvůli genderově rozděleným pracím. Společenský řád také vytvořil modely s povoláními orientovanými pouze na muže a podporoval tabu zamezující vykonávat určité druhy práce ženami. Se zvyšující se urbanizací, rostoucí infrastrukturou a př́livem ropných financí i zahraničních investorů a obchodníků se tato situace změnila a ženy se začaly objevovat v zaměstnání i ve státním sektoru, na úřadech či jiných institucích a v soukromém podnikání. Zaměstnávání žen ve státním sektoru se koncentrovalo především na oblast zdraví, vzdělání, sportu a komunikace, nikterak v politických službách. Maloobchod a služby byli rovněž především doménou mužů (a stále tak můžete dnes vidět bázáry, kterým dominují či je dokonce naprosto ovládají muži). Ženám z nižších tříd či s nižším vzděláním byla vyhrazena domácí sféra tak, aby nebyly vidět na veřejnosti (Dallalfar 1994: 548).

Univerzitním vzděláním v Íránu v současnosti disponuje stále více žen, avšak dle některých autorů je tř̌ba více strukturálních změn ve společnosti a systému vzdělávání. Stále je totiž dodržována genderová hierarchie, a u moci tak zůstávají výhradně muži (Rahbari 2016: 1008). Vysokoškolské vzdělání, jak potvrzuje například informátorka M., rozšířilo obzory jen těm, které chtěly nebo měly možnost studovat bez rodičovské kontroly (Informátorka M. 2020a). Vrátím-li se zpět k feministickým snahám, budoucí aktivistky, ale také obhájkyně lidských (a ženských) práv 
plodí právě univerzita, která se tak významně podílí na celospolečenské změně (Włodek-Biernat 2010: 506).

\section{Závěr}

Otázka kulturní transmise a změny životního postavení zkoumaných žen byla specifikována na tématech soukromé a veřejné sféry (rodiny, zahalování jako jednoho z prostředků patriarchátu, sociální kontroly přítomné ve veřejné sféře a univerzitního vzdělání jako společenské změně). Na základě realizovaných studií zahraničních autorů se do značné míry potvrdily základní premisy, které předcházely tomuto textu. Např́iklad, že patriarchát není statickou kulturní jednotkou upoutanou na místo, ale přemistuje se spolu s nositeli kultury.

Povaha výzkumného tématu odkazuje na současné transnacionální trendy - naznačuji, že informátorky se pohybují v meziprostoru, neukotveny ani v zemi původu, ani v emigraci, zároveň si udržují transhraniční vazby a účastní se dění v obou (sociálních) světech (Henig 2007: 96). Íránské ženy odešly ze své země, ve které muži rozhodovali o jejich životě, aby se tak přivdaly do kultury, v níž ale jejich původ určuje, jakou společenskou roli hrají.

Ženy, netušíce, si nesou svou kulturu s sebou, at už v podobě vazeb, které stále udržují na zem původu skrze rodinu, přátele, ale také skrze vlastní jednání, které je do značné míry závislé na životě v minulosti.

Úleva se dostavila skrze odložení šátku a možnosti přizpůsobit svůj vzhled vlastnímu vkusu, zároveň s tím ale přišlo odhalení se zbytku společnosti. Fyzickými rysy ženy zas a znovu upoutávají pozornost veřejnosti, ve které se necítí být vítány. Důvodem je, kromě odlišného fyzického vzhledu, neznalost jazyka, a tedy neschopnost účastnit se pracovního života, ale také volnočasových aktivit. Jelikož ženy, jak jsem v textu popsala, netvoří komunitu, která by udržovala vzájemné styky, jsou v pro ně stále cizím prostředí osamocené. Nemohou se spřátelit s českými ženami - nejen pro neznalost češtiny, ale také právě vlivem kulturních odlišností. Nenachází společné téma a sdílenou zkušenost. S íránskými ženami se ale nestýkají, jako by chtěly zapomenout na svůj původ a nevytvářet si na něj další vazby. Přesto, domnívám se, zároveň nevědomky, možná v pudu sebezáchovy vazby na íránskou kulturu udržují např́klad skrze vztahy s rodiči, ačkoliv ty jsou poznamenané. Informátorky díky technologiím komunikují se svými rodiči pravidelně, nenechávají je ale zasahovat do soukromých záležitostí. Jak popisuje informátorka M. svůj vztah s matkou, jedná se o povrchní, možná až pokrytecký vztah poznamenaný minulými výčitkami, ale je důležitý, nejdůležitější v jejím životě (Informátorka M. 2019a).

Studie by mohla upozorněním na marginální menšinu žijící u nás přispět do diskuze o takzvaném kulturním rasismu, tedy intolerancí k lidem z takzvaných zemí třetího světa (Moghissi 1999: 209), který také do značné míry souvisí s historickým odkazem kolonialismu. Tak jako posuzujeme či zkoumáme ty druhé, často se upínáme k potřebě kolonialistické agendy zachraňovat íránské ženy před jejich muži (Bahramitash 2008).

\section{Financování}

Text je dílčím výstupem projektu SGS-2020-002 „Dynamika změn na Blízkém východě a v Africe“ financovaného Západočeskou univerzitou v Plzni.

\section{Bibliografie}

Axworthy, M. 2014. Dějiny Íránu. Praha: Nakladatelství Lidové noviny. 
Bahramitash, R. 2008. „Saving Iranian Women: Orientalist Feminism and the Axis of Evil." Pp 101-110 in B. Sutton, S. Morgen, J. Novkov (eds.). Security Disarmed: Critical Perspectives on Gender, Race, and Militarization. New Brunswick, New Jersey, London: Rutgers University Press.

Benjamin, M. 2018. „The Paradoxical Status of Iranian Women." Pp 101-120 in Inside Iran: The Real History and Politics of the Islamic Republic of Iran. New York, London: OR Books. https:// doi.org/10.2307/j.ctv62hfzm.

Çevik, M. 2013. "God and Gender in Islam.“ Beytulhikme. An International Journal of Philosophy 3 (2): $2-12$.

Dallalfar, A. 1994. „Iranian Women as Immigrant Enterpreneurs.“ Gender and Society 8 (4): 541-561. https://doi.org/10.1177/089124394008004005.

Henig, D. 2007. „Transnacionalismus.“ Antropo Webzin 2007 (2-3): 94-103.

Hesová, Z. 2019. „Secular, Islamic or Muslim feminism? The Place of Religion in Women's Perspectives on Equality in Islam." Gender a výzkum/Gender and Research 20 (2): 26-46. http:// doi.org/10.13060/25706578.2019.20.2.482.

Informátorka A. 2020. Osobní rozhovor. 10. ledna 2019.

Informátorka M. 2019a. Osobní rozhovor. 18. dubna 2018.

Informátorka M. 2019b. Osobní rozhovor. 14. listopadu 2019.

Informátorka N. 2020a. Osobní rozhovor. 30. ledna 2020.

Informátorka N. 2020b. Osobní rozhovor. 17. dubna 2020.

Informátorka S. 2020. Osobní rozhovor. 11. března 2020.

Informátorka Z. 2019. Osobní rozhovor. 15. listopadu 2019.

Janeček, P. 2014. „Etnografický výzkum.“ Pp 11-119 in R. Doušek a kol. Úvod do etnologického výzkumu. Brno: Ústav evropské etnologie Filozofické fakulty Masarykovy univerzity.

Keller, J. 2017. „Komunita.“ [online] Sociologická encyklopedie. Sociologický ústav AV ČR. [cit. 13. 4. 2020]. Dostupné z: https://encyklopedie.soc.cas.cz/w/Komunita.

Mehran, G. 2003. „Political Reform and Education in Iran.“ Comparative Education 39 (3): 311-329. https://doi.org/10.1080/0305006032000134391.

Ministerstvo vnitra České republiky. 2020. „Cizinci s povoleným pobytem.“ [online] Odbor azylové a migrační politiky. [cit. 9. 6. 2020]. Dostupné z: https://www.mvcr.cz/migrace/clanek/cizinci-s-povolenympobytem.aspx.

Moghissi, H. 1999. „Away from Home: Iranian Women, Displacement Cultural Resistance and Change.“ Journal of Comparative Family Studies 30 (2): 207-217. https://doi.org/10.3138/jcfs.30.2.207.

Moore, L. H. 1988. Feminism and anthropology. Minneapolis: University of Minnesota Press.

Naghibi, N. 2007. „Scopophilic Desires: Unveiling Iranian Women.“ Pp 35-73 in Rethinking Global Sisterhood: Western Feminism and Iran. Minneapolis, London: University of Minnesota Press. https:// doi.org/10.5749/j.cttts4mn.

Nassehi-Behnam, V. 1985. „Change and the Iranian Family." Current Anthropology 26 (5): 557-562. https://doi.org/10.1086/203340.

Özel Volfová, G., M. Holt. 2019. „Muslimské feministky a jejich hledání genderově rovnostářského islámu. “ Gender a výzkum/Gender and Research 20 (2): 3-24. http://doi.org/10.13060/25706578.2019.20.2.481.

Rahbari, L. 2016. „Women in Higher Education and Academia in Iran." Sociology and Anthropology 4 (11): 1003-1010. https://doi.org/10.13189/sa.2016.041107.

Rastegar, M. 2006. „Reading Nafisi in the West: Authenticity, Orientalism, and ,Liberating“ Iranian Women." Women's Studies Quarterly (The Global \&s the Intimate) 34 (1/2): 108-128.

Włodek-Biernat, L. 2010. „Iranian Women. Quest for Freedom and Equality. "Polish Sociological Review 172: 503-509.

\section{O autorce}

Michaela Vaňková je studentkou doktorského programu Etnologie Katedry antropologie Západočeské univerzity v Plzni. Ve svém výzkumu se zaměřuje na íránské ženy žijící u nás. Zúčastnila se několika studijních pobytů v Íránu, kde se věnovala studiu reálií šíitského islámu a perštiny. Podílí se na organizaci Festivalu arabské kultury. ORCID: https://orcid.org/0000-0002-2478-8213. 


\section{Summary}

The topic focusing on Iranian women living in our country is not easy to deal with. This text is an introductory probe that seeks to present the issue of cultural transmission and changes in the life status of the studied women. Based on studies carried out by foreign researchers, the basic premises that preceded this text were largely confirmed. For example, patriarchy is not a static cultural unit tied to a place but moves along with the bearers of the culture. Although the informants in the Czech Republic try to remove the metaphorical veil, in addition to the real one, that symbolizes subordination to men and the limited opportunity to participate in public space events, in the West, they might face a whispering back voice. It can be the voice of their mothers, fathers, or Iranian society that accuses them of inappropriate behaviour, together with the cultural patterns brought with them. Unsuspectingly, women are carrying their culture with them, whether in the form of ties they still maintain to the country of origin through family, friends, but also through their own actions, which are largely dependent on life in the past. Seemingly, the women considered themselves satisfied in Iran, but they did not achieve the desired happiness in the Czech Republic either. Their status changed from a marginalized woman whose life is decided by men to a marginalized woman of foreign origin, i.e. double marginalization. Relief came through the removal of the scarf and the ability to adapt her appearance to her own way, at the same time revealing herself to the rest of the society. Through physical features, women, again and again, attract the attention of the public, in which they mostly do not feel welcome. The reason is, in addition to a different physical appearance, ignorance of the language, and thus the inability to participate in working life but also leisure activities. Since women, as I have described in the text above, do not form a community that would maintain mutual relations, they still feel alone in a foreign environment. It is almost impossible to develop friendships with Czech women - not only because they do not speak the Czech language, but also because of cultural differences. They might struggle to find a common conversation topic and shared experience. But at the same time, they do not associate with Iranian women as if they wanted to forget their origin and not form further ties to it. Nevertheless, I believe, they unknowingly, perhaps in the instinct of self-preservation, maintain ties to Iranian culture through the relationships with their parents. Thanks to modern technologies, informants communicate with their parents on a regular basis, but do not allow them to interfere in their private matters. As the informant M. describes her relationship with her mother, it is a superficial, perhaps even hypocritical relationship marked by past remorse, but it is still highly important, the most important relationship in her life. 